\title{
Some noteworthy lichenicolous fungi from Khabarovsk Territory of Russia
}

\section{Zhurbenko $\mathrm{MP}^{1^{*}}$ and Tugi $\mathrm{EW}^{2}$}

${ }^{1}$ Laboratory of the Systematics and Geography of Fungi, Komarov Botanical Institute, Russian Academy of Sciences, Professor Popov 2, St.-Petersburg, 197376, Russia. E-mail: zhurb58@gmail.com

${ }^{2}$ Volochaevskaya 163, apartment 139, Khabarovsk, 680000, Russia. E-mail: edwardtugi@gmail.com

Zhurbenko MP, Tugi EW 2013 - Some noteworthy lichenicolous fungi from Khabarovsk Territory of Russia. Mycosphere 4(1), 46-51, Doi 10.5943 /mycosphere/4/1/3

Eight species of lichenicolous fungi are reported from the Russian Far East, seven of which are new to the area. Species concepts of Endococcus pseudocyphellariae and Subhysteropycnis maculiformans are broadened, and both species are for the first time reported from the Northern Hemisphere and on Pseudocyphellaria perpetua. Evernia esorediosa is a new host species for Lichenostigma maureri and Parmelia squarrosa for Phoma physciicola.

Key words - biogeography - Endococcus - Pacific coast of Russia - Subhysteropycnis - taxonomy

Article Information

Received 19 November 2012

Accepted 8 December 2012

Published online 28 January 2013

*Corresponding author: Mikhail Zhurbenko - e-mail - zhurb58@gmail.com

\section{Introduction}

Lichenicolous fungi of the non-arctic Far East of Russia are poorly known. This is particularly true to Khabarovsk Territory, where just 11 species have been reported (Zhurbenko 2007, 2010). Thus, it is not surprising that examination of a small lichen collection from this territory revealed several noteworthy finds of lichenicolous fungi.

\section{Methods}

The material was examined using Zeiss microscopes (Stemi 2000-CS and Axio Imager A1) equipped with Nomarski differential interference contrast optics. For microscopical examination material was mounted in water, $10 \% \mathrm{KOH}(\mathrm{K})$, Lugol's iodine, directly (I) or after $\mathrm{KOH}$ pre-treatment $(\mathrm{K} / \mathrm{I})$ or brilliant cresyl blue (BCr). The length, breadth and length/breadth ratio $(1 / \mathrm{b})$ of the ascospores and conidia are given as: $(\min -)\{\mathrm{X}-\mathrm{SD}\}-\{\mathrm{X}+$ $\mathrm{SD}\}(-\max )$, where $\min$ and $\max$ are the extreme values, $X$ the arithmetic mean, and SD the corresponding standard deviation. Measurements of ascospore sizes were rounded to the nearest $0.5 \mu \mathrm{m}$, those of conidiogenous cells and conidia to the nearest $0.1 \mu \mathrm{m}$. Measurements were taken from water mounts, unless otherwise indicated. Studied specimens are housed in LE and S herbaria.

\section{Results}

All specimens were collected by E. Tugi from one locality at the Pacific coast: Russia, Khabarovsk Territory, vicinity of MariinskoeReid village at Pereboevskii Gulf of Kizi Lake, $51^{\circ} 42^{\prime} \mathrm{N}, 140^{\circ} 19^{\prime} \mathrm{E}$, alt. $20 \mathrm{~m}$. 

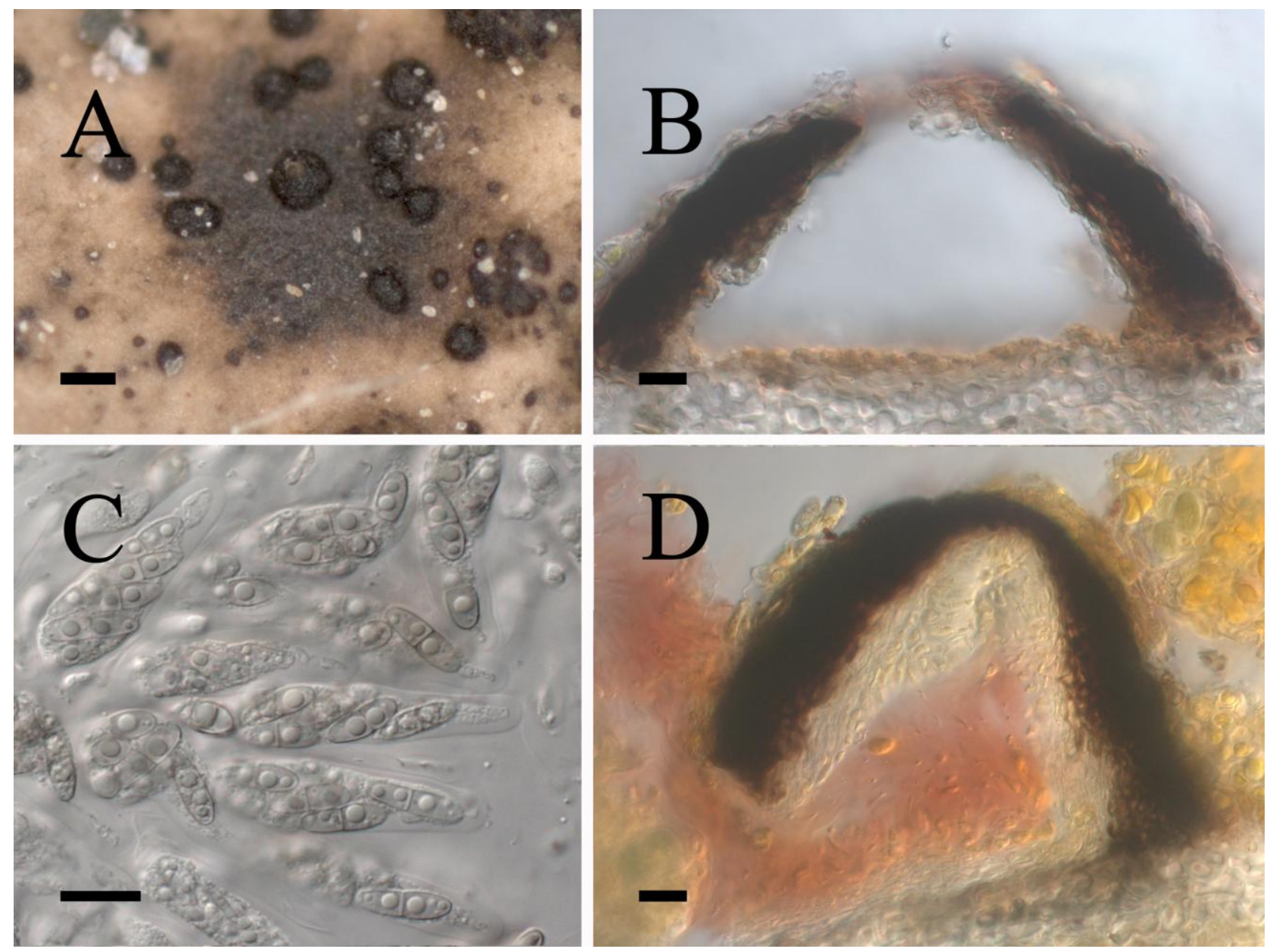

Fig. 1 - Endococcus pseudocyphellariae s. 1. (LE 260858). A ascomata habit. B old ascoma in cross section in $\mathbf{K}$. $\mathbf{C}$ asci and ascospores in water. $\mathbf{D}$ ascoma in cross section in I; note ostiolar filaments and staining of the hymenial gel with I. - Bars: $A=100 \mu \mathrm{m}, \mathrm{B}-\mathrm{D}=10 \mu \mathrm{m}$.

Abrothallus bertianus De Not.

Apothecia subglobose and somewhat applanate, constricted at the base, blackish brown, sometimes with obscure pruina, 150-250 $\quad \mu \mathrm{m} \quad$ diam. Epithecium yellow/orangish brown. Hymenium more or less colorless, here and there with lilac tinge, $\mathrm{K}+$ blue green. Ascospores yellow to pale brown, finally dark brown, distinctly verrucose, $(10.5-) 11-12(-13) \times 4.5-5(-5.5) \mu \mathrm{m}, 1 / \mathrm{b}=$ $(2.2-) 2.3-2.5(\mathrm{n}=12$, in water or K). Formerly known in Russia from the Caucasus, Karelia Republic, Pskov Region and Polar Ural (Zhurbenko \& Ahti 2005, Alstrup \& Ahti 2007, Otte 2007, Zhurbenko 2008).

Material examined - Mariinskoe-Reid, sparse Larix forest, on Melanohalea olivacea (apothecia, thallus) growing on larch branch, 7 Nov 2010, E. Tugi (LE 260828c).

Dactylospora parasitica (Flörke) Zopf Ascospores olive then brown, finely verruculose (under Nomarski microscopy), (1-)3-septate, $\quad\left(8.5^{-}\right) 10.5-12.5$ $(3.5-) 4-5.5(-7) \mu \mathrm{m}, 1 / \mathrm{b}=(1.4-) 2.2-2.8(-3.0)$ $(\mathrm{n}=24)$. Formerly known in Russia from the Caucasus and Taimyr Peninsula (Zhurbenko \& Santesson 1996, Otte 2004, Zhurbenko 2009a).

Material examined - Mariinskoe-Reid, old-growth Picea forest, on Pertusaria sp. (thallus) growing on spruce branch, 9 March 2011, E. Tugi (LE 260868).

\section{Endococcus pseudocyphellariae Etayo s. 1.}

Fig. 1

Vegetative mycelium pale brown, septate, cells $4-11 \times 3-3.5 \mu \mathrm{m}$, markedly constricted at the septa, immersed into cortex of host lobes. Ascomata perithecia, brownish black, glossy, hemispherical to often subconical, with flat base, occasionally with indistinct papilla, with ostiole $5-10 \mu \mathrm{m}$ diam., which is often hardly visible, $70-190 \mu \mathrm{m}$ diam., almost superficial, dispersed, 
occasionally adjacent; lateral wall dark brown, 6-20 $\mu \mathrm{m}$ thick (thinner near ostiole), in surface view resembling textura angularis or textura epidermoidea, of cells 4-6 × 3-4 $\mu \mathrm{m}, \mathrm{K}-$, $\mathrm{BCr}+$ blue-green; basal wall subhyaline, 5-12 $\mu \mathrm{m}$ thick, composed of several layers of elongated cells. Ostiolar filaments abundant, 6-10 $\times 1.5-2 \mu \mathrm{m}$; interascal filaments not seen. Hymenial gel I+ coral red, K/I+ blue. Asci narrowly lanceolate to obclavate, with distinct tholus and ocular chamber, (33-)34-48(-55) $\times(9-) 10-12 \mu \mathrm{m}(\mathrm{n}=22$, in water, $\mathrm{I}$ or $\mathrm{BCr}$ ), wall $\mathrm{BCr}-, \mathrm{I}-, \mathrm{K} / \mathrm{I}-, 8-$ spored. Ascospores hyaline or sometimes pale olive-brown, narrowly ovate to occasionally soleiform or clavate, (0-)1-septate, not or slightly constricted at the septum, $(8.5-) 10-12.5(-15) \times(3-) 3.5-4(-5) \mu \mathrm{m}, 1 / \mathrm{b}=$ $(2.1-) 2.5-3.5(-4.9)(\mathrm{n}=109$, in water, $\mathrm{BCr}$ or $\mathrm{K} / \mathrm{I}$ ), with one to several conspicuous guttules in each cell, smooth-walled, non-halonate, irregularly biseriate in the ascus, wall $\mathrm{BCr}-$. The fungus is mostly confined to old and/or somewhat discolored portions of host lobes, possibly it causes their slight discoloration.

There are some discrepancies when this specimen is compared with the species protologue (Etayo \& Sancho 2008). The asci of E. pseudocyphellariae were reported as being slightly longer $(53-58 \times 9-12 \mu \mathrm{m})$ and the ascospores permanently dark grey and slightly longer [(11.5-)13-15(-16) $\times 4-5 \mu \mathrm{m}]$. The mainly hyaline ascospores observed in the examined material are not typical for Endococcus, where they are supposed to be pale to dark brown (Kainz \& Triebel 2004). The species is known only from Pseudocyphellaria, with $P$. perpetua being a new host species. Formerly known only from the south of South America (Chile).

Material examined - Mariinskoe-Reid, old-growth Picea forest, on Pseudocyphellaria perpetua (upper lobe surface) growing on spruce branches, 9 March 2011, E. Tugi (LE 260858).

Lichenoconium erodens M.S. Christ. \& D. Hawksw.

The species is known from many regions of Russia, but is new to the Far East.
Material examined - Mariinskoe-Reid, on Lecanora symmicta (apothecia, thallus) growing on fence lignum, 29 Oct 2010, E. Tugi (LE 260818).

Lichenoconium lecanorae (Jaap) D. Hawksw.

Causes discoloration of host tissues. The species is known from many regions of Russia (Zhurbenko 2009a, b), but is new to the non-arctic part of the Far East.

Material examined - Mariinskoe-Reid, sparse Larix forest, on Melanohalea olivacea (hymenium of apothecia) growing on larch branch, 7 Nov 2010, E. Tugi (LE 260828b).

\section{Lichenostigma maureri Hafellner}

Formerly known in Russia from the Caucasus and Central and Southern Siberia (Navarro-Rosinés \& Hafellner 1996, Zhurbenko \& Davydov 2000, Zhurbenko \& Otnyukova 2001, Zhurbenko 2009b).

Material examined - Mariinskoe-Reid, sparse Larix forest, on Evernia esorediosa (thallus) growing on larch branch, 7 Nov 2010, E. Tugi (LE 260828a).

\section{Phoma physciicola Keissl.}

Conidiomata $80-120 \mu \mathrm{m}$ diam., almost completely immersed. Conidia ellipsoid to oblong, occasionally almost circular, rounded at both ends, usually with 1-2 large guttules, $(2.9-) 4.1-5.5(-7.0) \times(2.7-) 2.8-3.0(-3.3) \mu \mathrm{m}$, $1 / \mathrm{b}=\left(1.0^{-}\right) 1.5-1.9(-2.4)(\mathrm{n}=43)$. Exhibits strong pathogenicity as the infected host thallus surface is strongly bleached/reddish and surrounded by black rim. This species mostly grows on Physcia and Physconia, but was also reported on Parmelia s. str. (Brackel 2007, 2009) and is the only Phoma species known on the latter host genus. Parmelia squarrosa is a new host species. Formerly known in Russia only from Taimyr Peninsula and Chukotka (Zhurbenko 2009b).

Material examined - Mariinskoe-Reid, old-growth Picea forest, on Parmelia squarrosa (thallus) growing on spruce branch, 9 March 2011, E. Tugi (LE 260878).

Subhysteropycnis maculiformans Wedin \& Hafellner s. 1 .

Fig. 2 

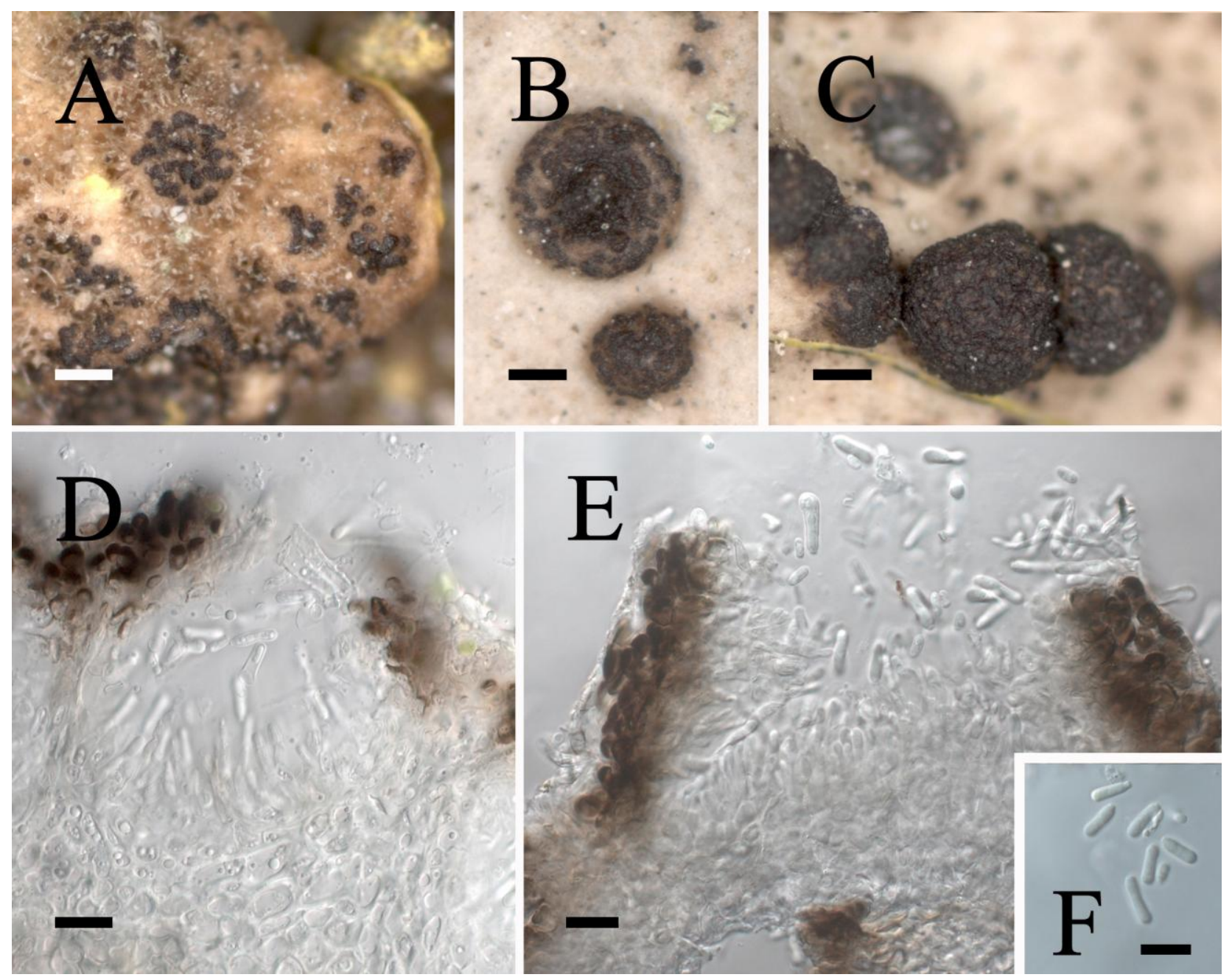

Fig. 2 - Subhysteropycnis maculiformans s. 1. (LE 260888). A-C: aggregations of conidiomata on lower (A) and upper (B, C) sides of host lobes; note different degree of gall formation. D, E: conidiomata in cross section in water. F: conidia in water. - Bars: $A-C=200 \mu \mathrm{m}, \mathrm{D}-\mathrm{F}=10 \mu \mathrm{m}$.

Conidiomata irregularly rounded to elongated in surface view, 40-120 $\mu \mathrm{m}$ wide, 30-60 $\mu \mathrm{m}$ tall, blackish brown, more brown when wet, glossy, with irregularly rounded or elongated ostiole 5-70 $\mu \mathrm{m}$ lengthways, often gaping (particularly when wet) and showing the interior of the conidiomata, erumpent, often flattened at the base and almost superficial when mature; lateral wall $8-15 \mu \mathrm{m}$ thick, composed of 2-3 layers of roundish cells, dark brown, pigmentation mainly located near cell walls, $\mathrm{K}+$ dark green; basal wall indistinct, hyaline; usually densely aggregated and often confluent, inducing conspicuous hemispherical galls up to $1.2 \mathrm{~mm}$ diam., which are dark brown due to the crowded conidiomata of the fungus. Section of conidiomata I+ red, K/I+ blue throughout. Conidiogenous cells mainly develop at the base of conidiomata, pyriform to ampulliform, ca. 7.5-9.5 × 3.5-4.5 $\mu \mathrm{m}$, with poorly visible collarette. Conidia bacilliform, straight to slightly curved, sometimes slightly constricted in the center, occasionally somewhat thicker above, with rounded apex and often with clearly truncate base, hyaline, smooth-walled, aseptate, often with 2-3 large guttules better seen in $K$, $\left(4.6^{-}\right) 8.1-10.5(-11.5) \times(2.0-) 2.5-2.9(-3.9)$ $\mu \mathrm{m}, 1 / \mathrm{b}=(1.9-) 3.0-3.8(-4.7) \quad(\mathrm{n}=136$, in water, I or K). Infected parts of the host lobes retain their normal color or become slightly darker.

Gall induction was not mentioned in Subhysteropycnis maculiformans protologue (Wedin \& Hafellner 1998), but has been observed by Etayo \& Sancho (2008). There are some other minor discrepancies with the species protologue, where its upper pycnidial wall was reported being $12-25(-35) \mu \mathrm{m}$ thick and composed of 4-10 cell layers, pycnidial 
gel I+ pale blue, and conidia $6.5-10.5 \times 1.5-3$ $\mu \mathrm{m}$. Wedin \& Hafellner (1998) suggested that Subhysteropycnis maculiformans represents an anamorph of Arthonia badia Wedin \& Hafellner. However, there is no direct cultural or molecular evidence to support this supposition and thus we follow Etayo \& Sancho (2008) who treated this coelomycete under a separate name. The species, as well as its suggested teleomorph, has previously been known only from the south of South America (Argentina and Chile) growing on Pseudocyphellaria granulata (Wedin \& Hafellner 1998, Etayo \& Sancho 2008). Pseudocyphellaria perpetua is a new host species.

Interestingly, there is one more similar gall-inducing coelomycete Stygiomyces galliformis Coppins \& S.Y. Kondr. known on the same host genus from Tasmania (Coppins \& Kondratyuk 1995). However, this species differs from Subhysteropycnis maculiformans by its creamy white conidiomata, hyaline to dilute yellowish brown pycnidial wall, and longer conidia measuring (14.4-) 16-25(-28.4) $\times$ 1.7-2(-2.5) $\mu \mathrm{m}$, which are 3-septate at maturity.

Material examined - Mariinskoe-Reid, old-growth Picea forest, on Pseudocyphellaria perpetua (mainly throughout upper side of the host lobes, occasionally on their underside near margins) growing on spruce branches, 9 March 2011, E. Tugi (LE 260888, S).

\section{Acknowledgements}

Dmitry Himelbrant is thanked for help with identification of host lichens. Javier Etayo and Mats Wedin provided valuable comments on Endococcus pseudocyphellariae and Subhysteropycnis maculiformans, and Ave Suija on Abrothallus bertianus.

\section{References}

Alstrup V, Ahti T. 2007 - New reports of lichenicolous fungi, mainly from Finland and Russia. Karstenia 47, 1-4.

Brackel W V 2007 - Weitere Funde von flechtenbewohnenden Pilzen in Bayern - Beitrag zu einer Checkliste III. Berichte der Bayerischen Botanischen Gesellschaft 77, 5-26.
Brackel W. v. 2009 - Weitere Funde von flechtenbewohnenden Pilzen in Bayern - Beitrag zu einer Checkliste IV. Berichte der Bayerischen Botanischen Gesellschaft 79, 5-55.

Coppins B, Kondratyuk SY. 1995 Stygiomyces and Pseudonitschkia: two new genera of lichenicolous fungi. Edinburgh Journal of Botany 52(2), 229-236.

Etayo J, Sancho LG. 2008 - Hongos liquenícolas del Sur de Sudamérica, especialmente de Isla Navarino (Chile). Bibliotheca Lichenologica 98, 1-302.

Kainz C, Triebel D. 2004 - Endococcus. In: Lichen Flora of the Greater Sonoran Desert Region, Vol. 2 (eds TH Nash III, BD Ryan, P Diederich, C Gries, F Bungartz). Lichens Unlimited, Arizona State University, Tempe, Arizona 648-651.

Navarro-Rosinés P, Hafellner J. 1996. Lichenostigma elongata spec. nov. (Dothideales), a lichenicolous ascomycete on Lobothallia and Aspicilia species. Mycotaxon 57, 211-225.

Otte V. 2004 - Flechten, Moose und lichenicole Pilze aus dem nordwestlichen Kaukasus - erster Nachtrag. Feddes Repertorium 115(1-2), 155-163.

Otte V. 2007 - Lichens, lichenicolous fungi and bryophytes from the north-west Caucasus - second supplement. Herzogia 20, 221-237.

Wedin M, Hafellner J. 1998 - Lichenicolous species of Arthonia on Lobariaceae with notes on excluded taxa. Lichenologist 30(1), 59-91.

Zhurbenko MP. 2007 - The lichenicolous fungi of Russia: geographical overview and a first checklist. Mycologia Balcanica 4, 105-124.

Zhurbenko MP. 2008 - Lichenicolous fungi from Russia, mainly from its Arctic. II. Mycologia Balcanica 5(1-2), 13-22.

Zhurbenko MP. 2009a - Lichenicolous fungi and some lichens from the Holarctic. Opuscula Philolichenum 6, 87-120.

Zhurbenko MP. 2009b - Lichenicolous fungi and lichens from the Holarctic. Part II. 
Mycosphere Doi 10.5943/mycosphere/4/1/3

Opuscula Philolichenum 7, 121-186.

Zhurbenko MP. 2010 - Lichenicolous fungi and lichens growing on Stereocaulon from the Holarctic, with a key to the known species. Opuscula Philolichenum 8, 9-39.

Zhurbenko MP, Ahti T. 2005 - A preliminary list of lichenicolous fungi of Republic of Karelia, Russia. In: Fungi in natural and anthropogenic ecosystems: Proceedings of the international conference dedicated to the centenary of the beginning by Professor A. S. Bondartsev his research activity at the V. L. Komarov Botanical Institute RAS (24-28 April, 2005, Saint Petersburg).
St.-Petersburg, 2005. Vol. 1. BIN RAN Press, St.-Petersburg, 194-200.

Zhurbenko MP, Davydov EA. 2000 Lichenicolous fungi and some lichens from the Russian Altai, southern Siberia. Folia Cryptogamica Estonica 37, 109-118.

Zhurbenko MP, Otnyukova TN. 2001 Lichenicolous fungi from the SayanTuva Mountains, Southern Siberia, Russia. Folia Cryptogamica Estonica 38, 79-84.

Zhurbenko MP, Santesson R. 1996 Lichenicolous fungi from the Russian Arctic. Herzogia 12, 147-161. 